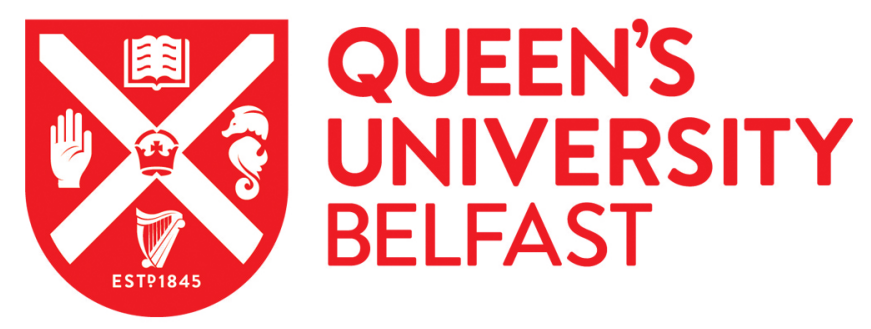

\title{
Eli Neira: Pursuing Community and Interconnectedness against the Commodification and Institutionalization of Culture in Chile
}

Bowskill, S., \& Lavery, J. (2020). Eli Neira: Pursuing Community and Interconnectedness against the Commodification and Institutionalization of Culture in Chile. Bulletin of Spanish Visual Studies, 4(1), 93. https://doi.org/10.1080/24741604.2020.1726066

\section{Published in:}

Bulletin of Spanish Visual Studies

\section{Document Version:}

Peer reviewed version

Queen's University Belfast - Research Portal:

Link to publication record in Queen's University Belfast Research Portal

Publisher rights

( 2019 Bulletin of Spanish Visual Studies. This work is made available online in accordance with the publisher's policies. Please refer to any applicable terms of use of the publisher.

\section{General rights}

Copyright for the publications made accessible via the Queen's University Belfast Research Portal is retained by the author(s) and / or other copyright owners and it is a condition of accessing these publications that users recognise and abide by the legal requirements associated with these rights.

Take down policy

The Research Portal is Queen's institutional repository that provides access to Queen's research output. Every effort has been made to ensure that content in the Research Portal does not infringe any person's rights, or applicable UK laws. If you discover content in the Research Portal that you believe breaches copyright or violates any law, please contact openaccess@qub.ac.uk. 


\title{
Eli Neira, Pursuing Community and Interconnectedness against the Commodification and Institutionalisation of Culture in Chile.
}

\author{
Sarah E. L. Bowskill (Queen’s University Belfast) (corresponding \\ author) \& Jane E. Lavery (University of Southampton) \\ @BowskillSarah \\ s.bowskill@qub.ac.uk
}

\begin{abstract}
Eli Neira (b. 1973) is a Chilean poet, artist, performer and blogger who resists traditional infrastructures of cultural production. The works studied in this article (an open letter to FONDART, 'Big Money’, 'Soy Terrorista: Anti Postal 6, al Mapuche en huelga de hambre,' 'Inmaculado Corazón' and 'Limpieza colectiva como obra de arte') address the issues of consumerism and art, the environment, and religion and sexuality but they are united by an overarching project which challenges the commodification and institutionalisation of culture by seeking out new outlets and audiences. In so doing, Neira seeks to occupy what she terms 'zonas intersticiales' (in-between spaces) or a 'zona peligrosa' (danger zone). This terminology, however, alerts, us to the inevitable contradictions in her practice as she resists, but is inevitably part of, the cultural field which she critiques. Neira's work, therefore, is significant because it helps us to understand resistance as relational and not as something that is 'outside'. Whilst her work alerts us to the limits of resistance, so too does it suggest more inclusive artistic practices which prioritise a sense of interconnectedness and community.
\end{abstract}

\section{Keywords}

Eli Neira, performance, (limits of) resistance, Chile, FONDART, 'Big Money', 'Soy Terrorista: Anti Postal 6, al Mapuche en huelga de hambre,' 'Inmaculado Corazón', 'Limpieza Colectiva Como Obra de Arte’

\section{Tweetable Abstract}

Analysis of strategies of resistance and community building employed by Chilean poet, artist, performer and blogger Eli Neira. \#latinamerican \#performance \#multimedia

@BowskillSarah@ModLangs_QUB@multimedia_18@ModernLangs@HumanitiesUoS

Eli Neira (b. 1973, Chile) produces challenging, deliberately provocative, multidisciplinary work. She prefers to publish in independent outlets and makes her work freely available online or in public spaces. In interviews and her written work she claims that decisions around the publication and dissemination of her work are strategic and are designed to resist commodification and institutionalisation. Her attention to the form of cultural production as well as to the content of her work places her in line with what Brian Whitener has termed, with 
reference to Mexican literature, 'a minor, but often overlooked, aesthetic tradition which distinguishes, as Walter Benjamin once put it, "between merely supplying a production apparatus and changing it"'. Although Neira is by no means alone in questioning contemporary cultural politics and its infrastructure, analysing the statements she has made we have identified Neira as someone who is articulating and developing through her creative practice an increasingly sophisticated alternative, collaborative approach to cultural production based on living in an interconnected community not bound by national borders. This overarching 'counter-hegemonic' artistic and intellectual project, is, to draw on Raymond Williams' definition, a project which aims to establish 'a new predominant practice and consciousness'. ${ }^{2}$ This article evaluates Neira's achievements in resisting the commodification and institutionalisation of her work and developing an alternative practice before considering how her endeavours cast light on the possibilities and limits of artistic dissent in a neoliberal and digital age.

The article begins locating Neira within the broader context of Chilean performance art as it stepped out of established theatre venues. It goes on to set out Neira's conceptualisation of her work as occupying a 'zona peligrosa' or 'zona roja de cultura'. In order to understand Neira's use of these terms we draw on Alexander Galloway and Eugene Thacker's concept of the hacker, Arjun Appadurai's rejection of the in-out binary and the imagined community of the nation in favour of non-nation based imagined worlds, Pierre Bourdieu's strategies of condescension, and Jocelyn A. Hollander and Rachel L. Einwohner's understanding of resistance as involving multiple stakeholders. Subsequently, we analyse how Neira has used her writing to critique the institutionalisation of culture notably in a parody of a public letter which she addressed to FONDART and in her blog posts about the commemorations of the bicentenary of Chilean Independence. Just as Neira embraces performance art over the more traditional proscenium-styled theatre, so too does she produce visual artworks which can be consumed outside art gallery settings and some audiences will experience her performances as visual culture objects in the form of still images and videos online. It is in this opening up of boundaries, the embracing of an 'expanded field', and the mixing of media where, Shannon Jackson suggests, performance studies comes into dialogue with visual cultural studies. ${ }^{3}$ It is similarly important to note that Neira's visual output is in constant dialogue with the nonvisual, that is the literary form. In all instances, there is a reciprocal function in the sense that the different media enrich and create fresh meanings for one another. The equally overlapping thematic concerns and crossing of generic boundaries in Neira's performances and art can be seen in the cases of the performance 'Big Money' and the artwork 'Inmaculado Corazón', which will be studied here. ${ }^{4}$ Both works are examples of how Neira critiques the

\footnotetext{
* We would like to thank Eli Neira for her comments and for permission to use images of her work. We would also like to thank Tori Holmes and Catherine Boyle for their generous feedback on earlier versions of this article.

${ }^{1}$ Brian Whitener, 'The Politics of Infrastructure in Contemporary Mexican Writing', in Mexican Literature in Theory ed. by Ignacio Sánchez Prado (New York: Bloomsbury, 2018), pp.261-78, p.263.

${ }^{2}$ Raymond Williams, Keywords. A Vocabulary of Culture and Society (London: Fontana Press, 1988), 145.

${ }^{3}$ Shannon Jackson, 'Performing Show and Tell: Disciplines of Visual Culture and Performance Studies', Journal of Visual Culture Vol 4(2) (2003), pp.163-177, p.167.

4 'Big Money', 2013, http://www.youtube.com/watch?v=2jjXdOPmcKk [video], (accessed 27 March 2019), and ‘Inmaculado Corazón’, http://elizabethneira.blogspot.co.uk/ (accessed 27 March 2019).
} 
commodification of art through her aesthetic choices and in the content of her work yet may also participate in the creation of what Rob Horning has described as '(a) neoliberal subjectivity' which structures 'the self as inherently entrepreneurial' ${ }^{5}$ 'Soy Terrorista': 'Anti Postal 6, al Mapuche en huelga de hambre' will be briefly examined in order to showcase how Neira's opposition to the State and consumerism also becomes enmeshed in a protest against neo-colonial racial discrimination. Finally, the performance 'Limpieza colectiva como obra de arte' will be examined in order to argue that Neira promotes interconnectedness and community through her work as part of an alternative, resistant practice. ${ }^{6}$ It is hoped that these reflections will provide insights which might be useful for understanding how other authors and artists whose work has a counter-hegemonic thrust might also find themselves in contradictory positions and how we can appreciate their efforts without overlooking such tensions.

According to an article published in Los Impresentables, ${ }^{7}$ which aims to identify and showcase the work of emerging poets, Neira identifies herself primarily as a poet whose artworks are offshoots of her poetic expression. Nevertheless, she has also come to be accepted as a visual artist in her own right. The article describes how she views her performances, art and poetry as inexorably interlinked as both inform and enrich one another. Indeed, as will be seen, Neira incorporates the literary form into the non-literary form. Much of Neira's work can be seen on her blog site which comprises texts written by her such as poems, short stories, essays on cultural or political matters, as well as her art collages, videos and photographs of her (musical) performances. ${ }^{8}$ Videos of her performances are also available on her YouTube and Vimeo sites. ${ }^{9}$ She was the editor in chief of the magazine Rabiosamente Independientes published by Abyecta Ediciones which is described as:

una editorial alternativa que se caracteriza por el bajo costo de sus ediciones que resultan ser de realización casera y artesanal. Los autores de su sello, dentro de los cuales ella se incluye por supuesto, se caracterizan por estar fuera de los circuitos artísticos dominantes o académicos y en gran variedad de casos por habitar en las provincias chilenas alejadas de la gran capital. Sin embargo, la propuesta no se encuentra cerrada a la participación de ningún autor y mantiene las puertas abiertas a todos aquellos que quieran colaborar o participar de ella. ${ }^{10}$

Neira is also responsible for establishing the independent art community action collective PoesiAcción (gestión de cultura requeteKontra Independiente). At her CasaAcción, she hosts artist residencies, organises community art litter picking events and workshops on performance art to foster a socially engaged (artistic) community and to champion the work of others.

\footnotetext{
${ }^{5}$ Rob Horning, The New Enquiry http://marginal-utility.blogspot.co.uk/2011/03/structuring-self-asinherently.html (accessed 31st March 2017).

${ }^{6}$ Eli Neira, http://elizabethneira.blogspot.co.uk/ (accessed 27 March 2019).

7 n.a., 'La poética del cuerpo', Los Impresentables, October 12, 2009

http://losimpresentables.wordpress.com/tag/abyecta-ediciones-rabiosamente-independientes/ (accessed 27 March 2019).

${ }^{8}$ Eli Neira, http://elizabethneira.blogspot.co.uk/ (accessed 27 March 2019).

${ }^{9}$ Eli Neira, https://www.youtube.com/user/elineira and https://vimeo.com/user7469997_ (accessed 27 March 2019).

${ }^{10}$ n.a., 'La poética del cuerpo', Los Impresentables, October 12, 2009.
} 
Despite Neira's prolific output and contribution to the burgeoning field of online and multimedia cultural production from Latin America there is only a small corpus of published critical work on this poet-artist in the form of some journalistic articles and some short academic studies. ${ }^{11}$ These articles mainly focus either on Neira's poetry or her performance art and only a few currently, and very briefly, explore the links between her different artistic, literary and digital outputs. This article, we believe, represents the most sustained analysis of her multimedia work, including her performances, artwork and writing, to date and incorporates new insights gained from our correspondence with Neira. It is the first to identify an overarching, yet constantly evolving, project which reaches across performance, visual culture and the literary as well as across different media and through which she seeks to resist the commodification and institutionalisation of culture instead promoting interconnectedness and community through her publishing choices and creative endeavours. This article, alongside our previous studies of Guatemalan performance artist and poet Regina José Galindo, Mexican author Ana Clavel, and visual artist Pilar Acevedo, also represents the latest step in an ongoing project working with Spanish American women authors and artists who are part of an emerging trend of creative practitioners whose rejection of media and disciplinary boundaries reflects their rejection of other established categories, hierarchies and boundaries. ${ }^{12}$

\section{Genealogies of Performance Art in Chile}

While Neira has yet to be the focus of sustained critical attention, her work can be located within the broader tradition of Chilean performance art and cultural production. Her work is broadly in the tradition of the Escena de Avanzada, a term coined by Nelly Richard and used to refer to the neo-avant garde artistic practices of the seventies and eighties. More specifically, her works build on the legacy of the Colectivo de Acciones de Arte (CADA) and Las Yeguas del Apocalipsis (1987-1997) as these groups adopted more confrontational strategies than those associated with Richard and the Escena. ${ }^{13}$ Neira's 'poesía de la acción' is reminiscent of CADA's 'art actions' which began in 1979. Just as CADA 'did not work with a structured or defined theoretical or written framework, but through pamphlets, poems, and provocative statements included as inserts, blank pages, etc., in a series of magazines and news

\footnotetext{
${ }^{11}$ See 'Eli Neira', Letras.mysite.com, http://www.letras.mysite.com/archivoeneira.htm (accessed 27 March 2019). See also: no author, 'Elizabeth Neira y David Añiñiir', 2012, http://metiendoruido.com/2012/03/el-ruidode-la-poesia-elizabeth-neira-y-david-aninir/eli-neira-2/ (accessed 27 March 2019); Marcela Rosen, 'Entrevista a Eli Neira', Escaner Cultural, 7 January 2012, http://www.revista.escaner.cl/node/1970 (accessed 27 March 2019); Miranda Francisco, 'Visceral: Contra-cultura', Cavila, 9 December 2010, http://www.cavila.cl/2010/12/09/visceral/ (accessed 27 March 2019); Diamela Eltit, 'Abyecta de Elizabeth Neira: Con manos impecables de manicure’, Letras.mysite.com, 2004, http://www.letras.s5.com/en201204.htm (accessed 27 March 2019).

${ }^{12}$ See: Jane Lavery and Sarah Bowskill, 'The Representation of the Female Body in the Multimedia Works of Regina José Galindo', Bulletin of Latin American Research 31.1 (2012), pp 51-64; Jane Lavery, The Art of Ana Clavel: Ghosts, Urinals, Dolls, Shadows and Outlaw Desires (Oxford: Legenda, 2015) and Sarah E.L.Bowskill, 'Bearing witness to Child Abuse and Trauma in Pilar Acevedo's Multimedia 'Fragmentos' Exhibition', Bulletin of Spanish Visual Studies, 2.1 (2018), pp.105-136. The next steps in this project include an edited volume, and other research publications, (online) residencies and exhibitions at the Winchester Gallery and Chapel Arts Studios in 2021.

${ }^{13}$ Héctor Domínguez, 'La yegua de Troya: Pedro Lemebel, los medios y la performance', Reinas de otro cielo: modernidad y autoritarismo en la obra de Pedro Lemebel, ed. by Fernando Blanco (Santiago: LOM editores, 2004), pp. 117-49, p. 124.
} 
publications' Neira prefers the modern day equivalents including blog and Facebook posts. ${ }^{14}$ Neira also prefers street performances to galleries just as Peters Nez describes how '(e)ven when CADA developed performances in art galleries, the primary interventions were mainly carried out in highly transited neighbourhoods, streets, and other places in Santiago. Its proposal was not only to question the privileged place of the museum tradition, but also to eliminate the distance between art and daily life'. ${ }^{15}$ Robert Neustadt further highlights the dual political and artistic project of CADA when he explains that 'by dismantling the hierarchies implicit in both "high art" and the military dictatorship, CADA attempted to simultaneously subvert military authority and cultural hegemony. ${ }^{16}$

While the critic Willy Thayer questions whether resistance was at all possible under the dictatorship, Neira's understanding of CADA's public performances as political interventions clearly chimes with that of Neustadt as she writes that she was inspired by

la capacidad de activar utopías o poéticas utópicas en un momento que no tenía nada de poético. La idea de borrar la frontera entre vida y arte; la idea de escultura social y la estrategia de usar la ciudad y la realidad por cruda que sea como materias primas. [...] Pero por sobre todo la idea de la utopía como salida a una realidad totalitaria, la poesía como posibilidad de vivir una vida verdadera. ${ }^{17}$

CADA's influence on Neira similarly becomes evident in her drive to recover the lost memories of CADA's/Escena's art during Augusto Pinochet's dictatorship (1973-1990). She researched the group and interviewed its members, Juan Castillo, Lotty Rosenfeld, Raul Zurita y Diamela Eltit, when she worked as a journalist:

estaba muy interesada en publicar notas acerca de esa historia borrada del arte en Chile. Lo sentía como un deber, además los 90 fue un momento en que muchos sentimos la necesidad urgente de narrar, de sacar a la luz, lo que había ocurrido en la dictadura y que se mantenía en un cuasi secreto. ${ }^{18}$

Neira and CADA share in common a desire to reach audiences beyond traditional performance spaces but, as Catherine Boyle observes with reference to theatre under Pinochet, not only were audiences scarce and street theatre risky but the performances were often subject to 'the demands of overburdened codes'. ${ }^{19}$ Now, performers, including Neira, have more freedom to speak out but still traditional performance spaces are restricted to a largely urban middle class which constitutes a minority of the population. ${ }^{20}$ Neira, therefore, follows CADA in favouring

\footnotetext{
14 Toms Peters Nez, 'Nelly Richard’s crítica cultural', 93.

15 Toms Peters Nez, 'Nelly Richard’s crítica cultural', 93.

${ }^{16}$ Robert Neustadt, (Con)fusing Signs, 29-30.

${ }^{17}$ Eli Neira, email to authors, 19 June 2017 22:07. For Thayer on the role of Richard in constructing the Escena through her criticism and the impossibility of resistance under dictatorship see: Willy Thayer, 'El golpe como consumación de la vanguardia,' Revista Extremoccidente, 2003, 2: 54-58 and 'Vanguardia, dictadura, globalización (La serie de artes visuales en Chile, 1957-2000)’, in Pensar en/la postdictadura, ed. by N. Richard and A Moreiras (Santiago de Chile: Editorial Cuarto Propio, 2001). See also discussion of Thayer and Richard's response in Peters Nez, 160-165.

${ }^{18}$ E. Neira, email to authors.

${ }^{19}$ Catherine Boyle, 'Text, Time, Process and History in Contemporary Chilean Theatre', Theatre Research International. 26:2 (2001), 181-89, 183.

${ }^{20}$ Catherine Boyle, 'Text, Time, Process and History in Contemporary Chilean Theatre', 183.
} 
public street performance as a means of widening access to the arts whilst also extending the potential reach of her work beyond its immediate context by making it available online. As Sebastián Vidal notes, post-dictatorship cultural producers emerged, took up the mantle of CADA and the Escena and pursued independent publishing ventures but it was not until the advent of the Internet that things radically changed: 'Pasamos de una editorialidad de arte limitada y de resistencia a una multiple y de código abierto; ahí sin duda hay un cambio radical' ${ }^{21}$ Neira operates in this new context publishing with alternative outlets and availing of the opportunities for self-publishing opened up by the Internet.

Just as the members of CADA were wary of the institutionalisation of their work postdictatorship so too has Neira grown increasingly sceptical of contemporary cultural funding bodies and especially FONDART (Fondo Nacional para el Desarrollo Cultural y las Artes). Prior to the creation of FONDART in 1992 and under the repressive context of the Pinochet regime, artists who were part of the Escena had already identified the need to eschew established cultural institutions and 'reexaminar la dependencia del objeto de arte a las instituciones que administran no sólo su distribución y consumo sino, sus valores de inscripción oficial y de aceptabilidad dominante.'22 They aimed to 'potencializar el trabajo de arte como fuerza disentidora de la autoridad y de sus normas de disciplinamiento del sentido' ${ }^{23}$ In order to avoid appropriation the artists generated within their works " "zones of resistance”, unassimilable to order and its logical functioning.' ${ }^{24}$ Within these 'zones of resistance' the spectator had to decode the 'art actions' with little or no assistance. Strategies identified by Richard used by the artists of the Escena include 'a particular use of photography, [...] the displacement of supports, the blurring of disciplinary boundaries and, generally, the use of multiple references and proliferating meanings' ${ }^{25}$ Neira's description of her performance art and poetry as a 'zona roja de la cultura' or a 'zona peligrosa,' which resists easy interpretation and assimilation, clearly call to mind the 'zones of resistance' established by the Escena.

The similarities between Neira and her predecessors could lead to accusations that her work is derivative or an example of 'pastiche', the uncritical imitation of past styles/voices, and thus lacking in self-criticality. However, it should not be seen as ‘blank parody’ but rather as a form of 'creative plagiarism' and one which is particularly powerful because it harks back to the context of dictatorship in order to speak of the present moment, inviting us to question (post)dictatorship inequalities. ${ }^{26}$ Her work is part of a 'recognizable tradition of Chilean, and indeed Latin American, performance art that is based on the principles of 'acto de intervención' ${ }^{27}$

\footnotetext{
${ }^{21}$ Francisco Villarroel, 'El negocio de los Fondos de Cultura', El Mostrador http://www.elmostrador.cl/cultura/2015/01/20/el-negocio-de-los-fondos-de-cultura/ (accessed 27 March 2019).

${ }^{22}$ Nelly Richard, ‘Márgenes e Institución. Arte en Chile desde 1973’, Contribuciones Programa FLACSO , 1987, http://flacsochile.org/biblioteca/pub/memoria/1987/000332.pdf. (pp.3-4) (accessed 27 March 2019).

${ }^{23}$ Richard, 'Márgenes e Institución', 4.

${ }^{24}$ Nelly Richard, Margins and Institutions: Art in Chile Since 1973 (Melbourne: Art \& Text 1986), 27.

${ }^{25}$ Vodanovic, 'Reception and Contingency in Recent Art from Chile', 275.

${ }^{26}$ Fredric Jameson, 'Postmodernism and Consumer Society', in The Anti-Aesthetic: Essays on Postmodern Culture, ed. Hal Foster (Port Townsend, WA: Bay Press, 1983), 111-25, 114.

${ }^{27}$ Domínguez, 'La Yegua de Troya', 124.
} 


\section{Theorising Resistance}

Neira's decision to pursue alternative outlets for her work and her use of diverse cultural forms is part of an overarching strategy to create and occupy a site of resistance that has not been colonised by cultural institutions in order to provoke debate in the public sphere. Neira frames her work as a destabilising critical practice referring to it as a 'zona roja de la cultura' or a 'zona peligrosa'. ${ }^{28}$ The term 'zona peligrosa' captures the sense that her work is part of the cultural field but it also challenges the boundaries, hierarchies and assumptions on which that category and its institutions are constructed. 'Zona roja' in particular can be said to point to her deliberately provocative statements against, for instance, Chile's discourse of 'progress' and inadequate neoliberal environmental rhetoric, as well as its neo-colonial racism (as we see in, for example, 'Soy terrorista', 'Big Money' and 'Limpieza') and her explorations of erotic, sexualities and gender in her work - and as we shall see later specifically in 'Inmaculado Corazón'. Such incitement forces her audiences to confront that which they prefer to keep repressed and which are often forced to exist in the margins of the mainstream. Both spaces challenge official attempts at containment and control.

Akin to hackers who look for 'exploits' or gaps in existing technologies 'projecting potential change through those holes', Neira can be said to try to alter the status quo through targeted interventions. ${ }^{29}$ Working in the 'red zone' of culture, she even describes herself as a kind of 'smuggler' or hacker who uses her interstitial status to her strategic advantage:

yo supe tempranamente que tenía que operar en zonas intersticiales, (la red por ejemplo) y que no iba a contar con una institucionalidad que me apoyara sino más bien todo lo contrario. En ese sentido sí me siento una contrabandista o un hacker, dado a que existo en un plano más inmediato y visible que un museo donde no entra nadie (En Chile es escasísimo el público que entra a los museos). Me siento una contrabandista porque he tenido que instalar contenidos críticos fuera de las instancias diseñadas para instalar esa crítica, espacios de arte contemporáneo, revistas especializadas, universidades. De alguna manera la carencia que me expulsa constantemente a una periferia, cada vez más querida, me ha jugado a favor en el sentido que me ha obligado a constituirme como un sujeto incómodo, pero activo y estratégico. ${ }^{30}$

The vocabulary Neira employs here to describe how she needs to find ways of working without having to rely on institutional support is striking for its rejection of the binary states of being 'in' or 'out'. Neira's occupation of a non-binary position in order to negotiate the complexities and contradictions of the new cultural economy and free herself from the limits of institutionalised culture or nation-states can be usefully understood with reference to the work of Arjun Appadurai. Appadurai alerts us to the need to abandon simplistic inside or outside

\footnotetext{
${ }^{28}$ Eli Neira, E. 'Hacia una po-etica de la acción (parte 1): Intentos de una personal historia sobre la performance’, Escáner Cultural, 13 December, 2012, http://revista.escaner.cl/node/6660 (accessed 27 March 2019).

${ }^{29}$ Alexander Galloway and Eugene Thacker, The Exploit (Minneapolis: University of Minnesota Press, 2007), 81.

${ }^{30}$ E. Neira, email to authors.
} 
models and to move beyond 'existing center-periphery models (even those that might account for multiple centers and peripheries)' because 'the new global cultural economy has to be understood as a complex, overlapping, disjunctive order'. ${ }^{31}$ As the boundaries multiply and shift, yet become less distinctive, the poet-artist struggles to negotiate neoliberal economic and cultural logics. That is not to say though that dissent has been quashed because globalised free markets that are the product of neoliberal agendas, combined, as will be seen, with digital technologies, also lead to the emergence of new (virtual) spaces from which to present alternative views. These new spaces lead to new 'imagined worlds' which are 'constituted by the historically situated imaginations of persons and groups spread around the globe' who, having developed this broader perspective, 'are able to contest and sometimes even subvert the "imagined worlds" of the official mind and of the entrepreneurial mentality that surround them' ${ }^{32}$ As we shall examine, the creation of new networks and connections is at the heart of some of Neira's work. In bypassing traditional modes of representation and distribution networks, as well as establishing alternative creative outlets and communities, Neira can be seen to strive for an interconnected world.

Neira's positioning of herself in a 'zona peligrosa' may be understood as an example of what Pierre Bourdieu has called a 'strategy of condescension.'33 Strategies of condescension 'are those symbolic transgressions of limits which provide, at one and the same time, the benefits that result from conformity to a social definition and the benefits that result from transgression'. ${ }^{34}$ Crucially, Bourdieu notes that such strategies are:

reserved for those who are sufficiently confident of their position in the objective hierarchies to be able to deny them without appearing to be ignorant or incapable of satisfying their demands. ${ }^{35}$

Strategies of condescension, therefore, are only available to those, such as Neira, who at one time at least enjoyed some degree of consecration before she became more outspoken, and who, secure in their identity and position can afford to 'play with the rules of the cultural game' and benefit from doing so. ${ }^{36}$ Neira, for example, worked as a journalist and received funding from FONDART early in her career. She has been invited to give talks about poetry at universities, which are institutions which effectively sanction culture. She has also participated in poetry workshops in collaboration with mainstream and consecrated poets such as Carmen Berenguer and Gonzalo Millán who have both been awarded prestigious literary awards such as the Chilean Government's prestigious Premio Iberoamericano Pablo Neruda (Milán, 1987; Berenguer, 2008) ${ }^{37}$ and have supported Neira's poetic work. Such backing concedes Neira legitimacy as well as symbolic capital. Thus, while Neira's work has a clearly and increasingly

\footnotetext{
${ }^{31}$ Arjun Appadurai, 'Disjuncture and Difference in the Global Cultural Economy', in Theory, Culture and Society, vol. 7 (1990), 295-310, (296), DOI: 10.1177/026327690007002017.

${ }^{32}$ Appadurai, 'Disjuncture and Difference in the Global Cultural Economy', 296-7.

${ }^{33}$ Pierre Bourdieu, Language and Symbolic Power, ed. John B. Thompson (Harvard: Harvard University Press, 1991), 124.

${ }^{34}$ Bourdieu, Language and Symbolic Power, 124.

${ }^{35}$ Bourdieu, Language and Symbolic Power, 69.

${ }^{36}$ Bourdieu, Language and Symbolic Power, 125.

${ }^{37}$ Poet Elvira Hernández was awarded the prize in 2018.
} 
oppositional stance she benefits from some status in the cultural field and its associated institutions even as she tries to negotiate new positions and relationships within it.

The term 'strategy of condescension' implies a tactical intervention but we should note that Neira presents her practice as an explosive one coming from the margins rather than as a calculated risk measured against the potential rewards offered by institutional recognition and state funding. However, she concedes that even this marginal space of resistance is increasingly invaded by what she termed earlier as 'los circuitos del arte' presumably referring to what in Bourdieusian terms would be the members and institutions of the artistic field which create value including 'academies, journals, magazines, galleries, publishers, etc. ${ }^{38}$ In Neira's view, these actors co-opt the space for dissent and so neutralise the threat it poses to the established order. $^{39}$ This description of how her space of resistance is being colonised is typical of the way in which cultural products, events and even protest movements can be co-opted. In a Chilean context, Joanna Crow notes, for example, that Mapuche culture and history was sometimes coopted by the Pinochet regime. ${ }^{40}$ Nevertheless, Crow reminds us that we must not overlook the ways in which such events still allowed opportunities for the Mapuche community to 'voice their concerns' and 'use this space to challenge government policy' ${ }^{41}$ Today, in her (art) activism Neira collaborates with, amongst other groups perceived as dissident by the Chilean government, Mapuche political prisoners and the feminist, human rights and environmentalist group AMAPU. Yet, as will be discussed in the final section, her community-based environmental art activism could be co-opted by narratives which seek to justify the state's abdication of environmental responsibilities. Thus, Neira's work and experiences remind us that we must be attentive to the fact that resistance always involves negotiation between parties whose relationship is in flux and that her 'zona peligrosa' and 'zona roja' is a (potentially) contested space which is constantly 'becoming'.

Jocelyn A. Hollander and Rachel L. Einwohner's work captures the way in which resistance involves multiple stakeholders. In keeping with Neira's concept of the 'zona peligrosa' which is neither 'in' nor 'out', resistance, Hollander and Einwohner demonstrate, cannot be external as implied in Chantal Mouffe's discussion of the 'hegemonic approach', which challenges

\footnotetext{
${ }^{38}$ Pierre Bourdieu, The Field of Cultural Production, ed. Randal Johnson (Cambridge: Polity Press, 1993), p.32

${ }^{39}$ Eli Neira, E. 'Hacia una po-etica de la acción (parte 1)' , http://revista.escaner.cl/node/6660 (accessed 27 March 2019).

40 Joanna Crow, The Mapuche in Modern Chile. A Cultural History (Miami: University of Florida Press, 2013), 159.

${ }^{41}$ Crow, The Mapuche in Modern Chile, 159-60. Despite the fact that social media can be both a site of resistance and a space where such resistance can be co-opted. Neira uses the mainstream platform of Facebook (https://www.facebook.com/elizabeth.neira.12, (accessed 27 March 2019) in order to give visibility to the repression of Mapuche communities by the Chilean government. See her posts about the hunger strikes of Mapuche political prisoners (29/09/2017) and her performances in prisons also involving Mapuche political prisoners as a protest against neo-colonial racial oppression ('Variaciones de un gesto bíblico,' 25 December 2016, http://elizabethneira.blogspot.co.uk/ (accessed 27 March 2019).
} 
the view that institutions cannot be transformed and that resistance can only develop and be successful outside them, it stresses the necessity of combining the political strategies in art and artistic strategies in politics. ${ }^{42}$

Thus Hollander and Einwohner note, there are 'two recurring issues in discussions about the definition of resistance: recognition and intent'. ${ }^{43}$ Within their typology resistance could fall into the type 'missed resistance' whereby resistance is 'recognized by their target but unrecognised by third party observers' were it not for the fact that resistance becomes 'overt', to use Hollander and Einhower's term, and visible to third party observers. In Neira's case resistance becomes overt to a relatively limited audience at the moment of the initial performance and subsequently to a potentially wider audience through various online platforms. Seen in this light, Neira's online creative works as well as her Facebook or blog interventions are the culmination of her practice of resistance although, as Ulises Mejias suggests, we might think twice about what resistance via social media means when it feeds into the profits of large corporations. ${ }^{44}$ As will be seen, although her work has been censored by Facebook, Neira directs much of her critique towards cultural institutions and especially towards FONDART and less towards the social media corporations which open up spaces for resistance but are also 'part of a capitalist order that produces inequality' ${ }^{45}$

\section{Writing Against the Institutionalisation and Bureaucratization of Culture}

FONDART is the national funding body responsible for the funding of the arts in Chile and, for Neira, it is associated with a neoliberal, market-driven approach to culture. Neoliberalism was pioneered in Chile under the Pinochet regime and continues to underpin the government's approach to culture. As David Harvey explains, under neoliberalism the state is responsible for ensuring the functioning of the markets and creating institutions to facilitate them but 'beyond these tasks the state should not venture' ${ }^{46}$ In the 1990s, the neoliberal agenda sought to create a market for cultural entrepreneurs based on generating profit from cultural production and establishing creative industries. Public services were decentralised, and the role of the private sector grew. The government began to collaborate with the non-profit sector to create publicprivate partnerships and introduced arts funds such as FONDART. ${ }^{47}$ Today, the arts funds include: Fondart (regional and national), the Fondo Audiovisual, the Fondo de la Música and the Fondo de Fomento al Arte en la Educación. In 2003, the Consejo Nacional de la Cultura $y$ las Artes de Chile (CNCA) was established and the various Fondos brought under its control. The text of the law which created the CNCA confirms its neoliberal apolitical characteristics, describing it as: 'un servicio público autónomo, descentralizado y territorialmente

\footnotetext{
${ }^{42}$ Chantal Mouffe, 'Artistic Strategies in Politics and Political Strategies in Art', Dissidence, 10:2 (2013) http://hemisphericinstitute.org/hemi/en/e-misferica-102/mouffe (accessed 27 March 2019).

43 Jocelyn A. Hollander and Rachel L. Einhower, 'Conceptualising Resistance', Sociological Forum, vol. 19 no.4 (2004), 533-54, 534.

${ }^{44}$ Ulises A. Mejias, Off the Network, (Minneapolis: University of Minnesota Press, 2013), Chapter 1.

${ }^{45}$ Ulises A. Mejias, Off the Network, Chapter 1.

${ }^{46}$ David Harvey, A Brief History of Neoliberalism (Oxford: Oxford University Press 2005), 11.

${ }^{47}$ On the history of the arts funds see Javier Stanziola, 'Neoliberalism and Cultural Policies in Latin America: The Case of Chile.'
} 
desconcentrado, con personalidad jurídica y patrimonio propio, que se relacionará directamente con el Presidente de la República'. ${ }^{48}$ Moreover, Article 3 part 10 of the Law states that one of the functions of the CNCA is to: 'Desarrollar la cooperación, asesoría técnica e interlocución con corporaciones, fundaciones y demás organizaciones privadas cuyos objetivos se relacionen con las funciones del Consejo, y celebrar con ellas convenios para ejecutar proyectos o acciones de interés común. ${ }^{49}$ An apolitical arts organization may be seen as a positive development, but substituting political motivations in favour of commercial imperatives and works with wider appeal simply creates a different set of problems. It is this surrendering of the cultural arena to market imperatives which Neira tries to resist.

In 2003, Neira received FONDART funding to help her to develop a video installation based on her collection of poems Abyecta entitled ‘Abyecta Poesía en Expansión’. Such funding not only bestows a form of cultural capital but also provides a means of survival in what is otherwise a precarious profession from which it is difficult to earn a living. Subsequently, however, Neira became outspoken in her criticism of FONDART and seems to view her past success as being attributable to her then position as a journalist. The performance-poet-artist clarifies that

en mi periodo de periodista cultural, es decir cuando yo trabajaba desde un lugar de cierto poder dentro del stablisment cultural chileno, yo fui llamada para ser jurado del FONDART y también fue bastante fácil para mi ganarme algunos proyectos. ${ }^{50}$

The situation changed, however, when she gave up this privileged position to dedicate herself to her art: 'Después de dejar de "servirles”, perdí valor, me convertí en artista sin filiación, o sea en un parea'. ${ }^{51}$ She continues: 'Inmediatamente después, cuando me enfrenté al FONDART como artista, todo cambió y no sólo no fue fácil ganarme nada sino que hasta me dijeron que yo estaba en una lista negra por haberme burlado en un texto (de ficción) de la ministra de cultura de aquel entonces' ${ }^{52}$ Having relinquished her position as a journalist, Neira's position in the cultural field was no longer secure and she also lacked status to lend legitimacy to FONDART as a judge.

As a cultural commentator Neira may have been able to adopt a strategy of condescension, but once she opted out of that sphere we may surmise that she either 'fell off the radar' of the funding body or her criticisms (not only of FONDART, but also of the Chilean Government, as we shall see) directed from her new position in the 'zona peligrosa' were viewed as a more threatening kind of resistance and dealt with accordingly. The fact that she was an insider who, apparently voluntarily, gave up her privileged status sets her apart from the majority of artists who have often no choice but to work outside the funding system and also makes her potentially

\footnotetext{
${ }^{48}$ LEY NUM. 19.89, https://www.leychile.cl/Navegar?idNorma=213895, (accessed 27 March 2019).

${ }^{49}$ LEY NUM. 19.89, https://www.leychile.cl/Navegar?idNorma=213895, (accessed 27 March 2019).

${ }^{50}$ E. Neira, email to authors, 19 June 2017 22:07.

${ }^{51}$ E. Neira, email to authors.

${ }^{52}$ E. Neira, email to authors.
} 
more threatening to those institutions she now challenges. Had she not made her views and experiences public her actions would have been an example of 'missed resistance'. In order to make her resistance overt she needed to make it widely visible. Neira's public attack against FONDART took the form of a parody of the open letter format typically used by dissenting authors and artists and can be understood in the context of a generalised disenchantment felt by critics in Chile about the lack of transparency of the government's funding body and its selection criteria. ${ }^{53}$ Indeed, whilst graphic art technician Joselyn Figueroa states in relation to FONDART that 'es un misterio quiénes eligen los proyectos, bajo qué criterios y cuáles son sus prioridades', artist Alejandra Prieto criticises the fact that 'muchas veces tocan evaluadores con menos experiencia que el propio postulante, lo que puede resultar en equivocaciones' ${ }^{54}$ Each year, when the funding body makes public a document listing the projects which have received funding, artists, including Neira, protest against the funding body and its decisions. The protest, like Neira's parody of an open letter, is key in making resistance visible to third parties and therefore overt but in opting to intervene creatively she sets herself apart.

In the witty open letter to FONDART Neira criticised the iniquitous mechanisms FONDART uses to select potential award holders. Such a playful approach is the hallmark of the way in which she tries to use humour to break into public debate. Here she explains why she is writing rather than applying for funding through the usual channels:

En mi calidad de joven autora, fiel representante de la última hornada de creadores chilenos, me voy a tomar la libertad de dirigirme a ustedes, a través de la presente con el afán de solicitarles ciertos fondos, no concursables, que yo como artista creo merezco de sobra y que por una ceguera burocrática y un imperdonable error histórico se me han negado por las vías regulares (postulaciones a concursos nacionales y esas instancias menores). ${ }^{55}$

Neira goes on to list how she would spend these 'ciertos fondos' in order to 'vivir del Estado y quiero vivir bien', purchase a house with servants, to get a surgical make-over: 'como yo trabajo con el cuerpo intervenido por la poesía, usted sabe, debo lucir plástica y poética' and to purchase drugs which ‘juegan importante rol en el proceso de experimentación’. The humour in her remarks perhaps serves to soften their critical edge but also suggests that state funding is paltry despite popular beliefs that the grants are used to support a lavish lifestyle which has not been earned. Neira similarly mocks the tedium and bureaucracy involved in the grant

\footnotetext{
${ }^{53}$ FondART has been widely criticised for its funding choices and it is seen variously as too liberal and too conservative. FondART caused controversy in 2015 when it made a substantial award to CorpArtes the cultural foundation of Corpbanca owned by a multimillionaire. This led to an open letter signed by artists being published and shared on Facebook (https://www.facebook.com/notes/830232713702049/). See also: Diana Torres (2015) and Francisco Villarroel (2015) who notes that 'como todos los años, nuevamente este anuncio no estuvo exento de polémicas ácidas que activan el descontento del sector. Algunos ganan, otros pierden, y la lotería artística es repartida con un sabor amargo'.

${ }^{54}$ Quoted in Isabel Agurto et al. 'Ser artista en Chile: La importancia de las becas', Al limite, 7 January 2013, http://www.arteallimite.com/periodico/ser-artista-en-chile-la-importancia-de-las-becas (accessed 31 March 2019).

${ }^{55}$ Letter reproduced on the website: https://www.flickr.com/photos/34817846@N00/73488386 (accessed 31 March 2019).
} 
application process and humorously notes that she has sent via email both her CV ('el currículum se lo envío en dos correos separados, (ija, chiste!)’) along with a nude of herself.

Neira's tactic of publicly shunning established authorities is further illustrated in some of the comments she made in the run up to the bicentenary of Chilean Independence when she denounced the country's adoption of neoliberal cultural policies. As Suzana Milevska and Zhivka Valiavicharska have pointed out the "'biennialization” of contemporary art', the emergence of 'the idea of creative industries', and European funding for contemporary arts and culture all work to reinforce neoliberal political and economic agendas. ${ }^{56}$ Similarly, state funding of the arts in Chile can be seen to be used to set the agenda for cultural production in a way which is questioned by Neira. When asked '¿Qué te parece este Chile a portas del Bicentenario? ¿Su política cultural para con la Poesía?’ Neira responded:

Me parece una mierda, un país que instaló en todos los niveles la idea de neoliberalismo, un sistema cruel, competitivo, inhumano, antipoético y materialista hasta las cachas. Creo que para sobrevivir en este nuevo Chile hay que convertirse en una concha de su madre, no queda otra y la poesía, como el arte en general, se ubica en las antípodas de todo eso. Si la poesía es reflexión, tiempo, verdad, profundidad y belleza, es imposible sobrevivir en un entorno que te obliga todo el día hacer todo lo contrario. ${ }^{57}$

Neira has also criticised the Poquita Fe poetry festival, an event which is perceived by some as belonging to the cultural mainstream, as cultural critic Germán Garrido notes, not without irony:

hay una política cultural por parte del Estado mucho más vasta, en el contexto de una economía mucho más pujante, y, para más aún, se privilegian especialmente los subsidios a la poesía. Las empresas también auspician libros, eventos (Poquita $\mathrm{Fe}$, un festival minúsculo en cuanto a medios de producción a juzgar por sus integrantes de clase media casi todos estudiantes, contaba con el sponsoreo de Chilektra, la compañía más grande de electricidad a nivel nacional) como sucede en Europa y organizan concursos de poesía. Así es como la mayoría de los 30 poetas chilenos de entre 20 y 25 que conocimos había ya ganado un premio o conseguido una beca o un apoyo de algún tipo, de miles de dólares. ${ }^{58}$

In 2007 Neira denounced the festival for the apolitical nature of the poetry being presented:

lo que he visto en festivales como el poquita fe por ejemplo u otros en los que uno se encuentra con gente de su generación, pues me parece que bien, honesta, con fuerza, innovadora, un poco despolitizada no mas, eso es lo único que me parece

\footnotetext{
${ }^{56}$ Quoted in the chapter 'Neoliberalism' which consists of a discussion between Pamela Lee, Suzana Milevska, Isla Leaver-Yap, Shelley Errington, Shigemi Inaga, Keith Moxey, Bhaskar Mukhopadhayay, Susan BuckMorss, Angela Miller, Thomas Dacosta Kaufmann and Joyce Brodsky in Zhivka Valiavicharska James Zhivka Valiavicharska Elkins and Alice Kim eds., Art and Globalization Pennsylvania: Pennsylvania State University Press, 2010), pp. 85-96, 86, 88, 91.

${ }^{57}$ Neira quoted in Ernesto González Barnert, 'Elizabeth Neira', Letras.mysite.com, 2007, http://www.letras.mysite.com/en160507.htm (accessed 31 March 2019).

${ }^{58}$ Germán Garrido, 'La poesía se respira. Festival de poesía Poquita Fe de Santiago de Chile’ , Letras.mysite.com, 2004. http://www.letras.mysite.com/pf121204.htm (accessed 31 March 2019).
} 
un tanto preocupante, pero es un fenómeno global, como que la poesía se relata a si misma y no tiene mucha conexión con lo que pasa en el mundo inmediato. ${ }^{59}$

Despite this criticism and her promotion of her art as an independent practice and her poetry as being defined by its socio-political intent, Neira nonetheless participated in the festival in 2006. This decision further points to the way in which she adopts strategies of condescension where possible, operating in an in-between space reserving the right to criticise even when partaking in the benefits of cultural consecration. Such choices also suggest the difficulty of living up to high ideals or even a certain pragmatism. Similar tensions between high ideals and the need to survive may not be unique to Neira but they are perhaps particularly evident given the public nature of her denunciations.

Neira uses her blog to publicly express dissenting views about the institutionalisation and commercialisation of Chilean culture and how it impoverishes artists and the art that is produced. She questions the need for cultural institutions and the validity of their judgements that determine which texts can or cannot be included in the official national cultural canon via prizes. In one blog Neira writes:

¿De qué se trata exactamente inscripción social? ¿Quién inscribe, dónde, (en el canon o en la periferia) con qué autoridad y que implica? [...] la literatura, existe y existirá siempre más allá de las instituciones y de los autoproclamados inscriptores que pretenden repartir certificados de pertenencia o no pertenencia, porque (lo que se olvida demasiado a menudo) las instituciones culturales y sus directivas de inscriptores, se deben a la existencia de las manifestaciones culturales y no al revés. ¿Existe arte sin inscripción? Por supuesto, y mucho, tal vez el más interesante, ¿Hay institución de arte sin arte? Imposible. Por lo que tarde o temprano la institución deberá contener o dar cuenta de todo aquello que dice contener. De la misma manera que la existencia del estado se debe a la existencia del pueblo y no al revés. ${ }^{60}$

By questioning how value is created by cultural institutions and the basis on which decisions about the value of art are made Neira forces us, to borrow Dávila's words, to 'suspend the uncritical view that only cultural workers and initiatives that are properly institutionalized, packaged, and profitable are valuable' opening up 'broader definitions of value that account for the intangibles of social life, which are positively affected by cultural initiatives that may be discounted as insignificant according to the premises of neoliberal development'. ${ }^{61}$ In this way, rather than being a retreat from the world, Neira's relinquishing of a once privileged status becomes a political position of overt resistance that offers an alternative worldview to the one espoused by neoliberalising cultural policies and institutions.

\footnotetext{
${ }^{59}$ Eli Neira quoted in Ernesto González Barnert, 'Elizabeth Neira', Letras.mysite.com, 2007, http://www.letras.mysite.com/en160507.htm (accessed 31 March 2019). .

${ }^{60}$ Eli Niera, ‘A propósito de encuestas sobre institucionalidad en Chile,' April 2014 http://elizabethneira.blogspot.co.uk/2014_04_01_archive.html?zx=e462cc72a0220920 ) (accessed 31 March 2019).

${ }^{61}$ Dávila, Culture Works, 15.
} 
In the same blog post Neira lists a set of demands relating to the deinstitutionalisation of artistic production in Chile. She explains humorously, that she was going to post these demands via one of the government's online 'consulta ciudadana' initiatives but finally, she remarks with deep irony, chose not to send these because 'era una encuesta con preguntas dirigidas así como se dirige el pensamiento, y mi pensamiento se niega a llenar casilleros' ${ }^{62}$ Her decision not to send the document is ambiguous, it could represent a case of what Hollander and Einwohner define as 'covert resistance' whereby the resistance is intended by the actor and recognized by an observer but not by the target, in this case, the government. ${ }^{63}$ In this case, her actions in not sending the response could be seen as diminishing its contestatory power, as recognition of the futility of such an action or perhaps as the ultimate rejection of the government's authority as the only public that 'counts'. By replying to the people on a public forum her resistance is made more widely visible and arguably she is the one truly participating in a 'consulta ciudadana'. Neira's choice not to send the document perhaps reflects her knowledge that her unrealistic and counter-hegemonic requests would only fall on deaf ears. Neira's requests for the liberalisation of the arts include:

1) Que la intervención del estado en la cultura sea para facilitar la producción, visibilidad y la continuidad de todas aquellas prácticas culturales que quedan fuera de los circuitos tradicionales y académicos [...]

2) Entender la producción cultural como un motor generador de identidad y no como una plataforma colonizada y extranjerizante. En este sentido entender que la única industria cultural posible es aquella identitaria y no una meramente imitativa y mercantil de consumo rápido y asegurado.

The first statement points, however, to an underlying irony that once the state intervenes in a cultural inclusion programme which supports fringe artistic practices, then those same practices which thrive on working against traditional cultural networks would no longer operate as such as they would risk simply becoming absorbed into the cultural hegemony.

\section{Money, Money, Money}

Neira's second demand cited above reveals how she rejects an understanding of art as a product to be consumed or sold. However, just as she critiques the institutionalisation of culture whilst operating within, and sometimes soliciting the support of, cultural institutions, Neira also negotiates an in-between position when she criticises neoliberal markets whilst being inexorably caught up in them by, for example, selling her work online or by promoting her art and workshops via social networks.

\footnotetext{
62 Eli Neira, 'A propósito de encuestas sobre institucionalidad en Chile.’ http://elizabethneira.blogspot.co.uk/2014_04_01_archive.html?zx=e462cc72a0220920 ) (accessed 31 March 2019).

${ }^{63}$ Hollander and Einhower, 'Conceptualising Resistance’, 544.
} 
In her poem 'Soy terrorista' the poetic subject notes that she is anti-establishment and rejects the trappings of consumer culture which are the new markers of good citizenship:

Soy terrorista para el gobierno de mi país [...] no quiero represas en el sur / ni energía sucia de sangre que alimente al monstruo/Mórbido del hiper mercado neoliberal/ Soy terrorista porque no tengo trabajo estable [...] / Ni contrato / Ni chequera / Ni cuenta corriente /[...] / Porque no pago impuestos / Porque no soy una buena clienta de las casas comerciales /Porque ando en bicicleta o a pie/ porque tengo un amigo mapuche. ${ }^{64}$

The provocative use of the term 'terrorist' underscores the threat she poses to the system. She also poses a challenge to the establishment because of her (art) activist work with Mapuches, who have similarly been branded as 'terrorists' or as the 'enemy within' by the Chilean Government for their perceived dissident actions against the state’s abuses of indigenous rights.

The performance 'Big Money' (FIG 1) is a similarly acerbic attack on neoliberal markets which support the commercialisation or massification of art. Here, Neira is seen sitting at a restaurant table consuming not food, but dollars. ${ }^{65}$ Her grotesque and uncouth devouring of the notes becomes a broad critique of generalised consumerist greed. Given that the performance took place in Venezuela it can also be interpreted as a critical comment on the well-documented destructive effects North America's neoliberal practices have had (and continue to have) on Latin American society and economy as a whole. ${ }^{66}$ Neira's condemnation of mainstream culture as 'meramente imitativa y mercantil de consumo rápido y asegurado' ${ }^{67}$ is reinforced in 'Big Money' via her consumption of the notes which serve to critique insatiable (North American and Chilean) mainstream consumer culture or art and its imitative quality underpinned by the idea that each note is not an 'original' but a reproduction of a reproduction.

\footnotetext{
${ }^{64}$ Eli Neira, ‘Soy terrorista’, (http://elizabethneira.blogspot.co.uk/2012/01/comunicado-de-prensatremendo.html) (accessed 31 March 2019).

${ }^{65}$ Eli Neira, 'Big Money', https://www.youtube.com/watch?v=2jjXdOPmcKk, (accessed 31 March 2019).

${ }^{66}$ See Eric Hershberg and Fred Rosen, eds., Latin America After Neoliberalism: Turning the Tide in the 21st Century?, New York: New Press, 2006); Otero, Gerardo Otero, ed., Food for the Few: Neoliberal Globalism and Biotechnology in Latin America (Austin: University of Texas Press, 2008).

${ }^{67}$ Eli Neira, 'A propósito de encuestas sobre institucionalidad en Chile.'
} 


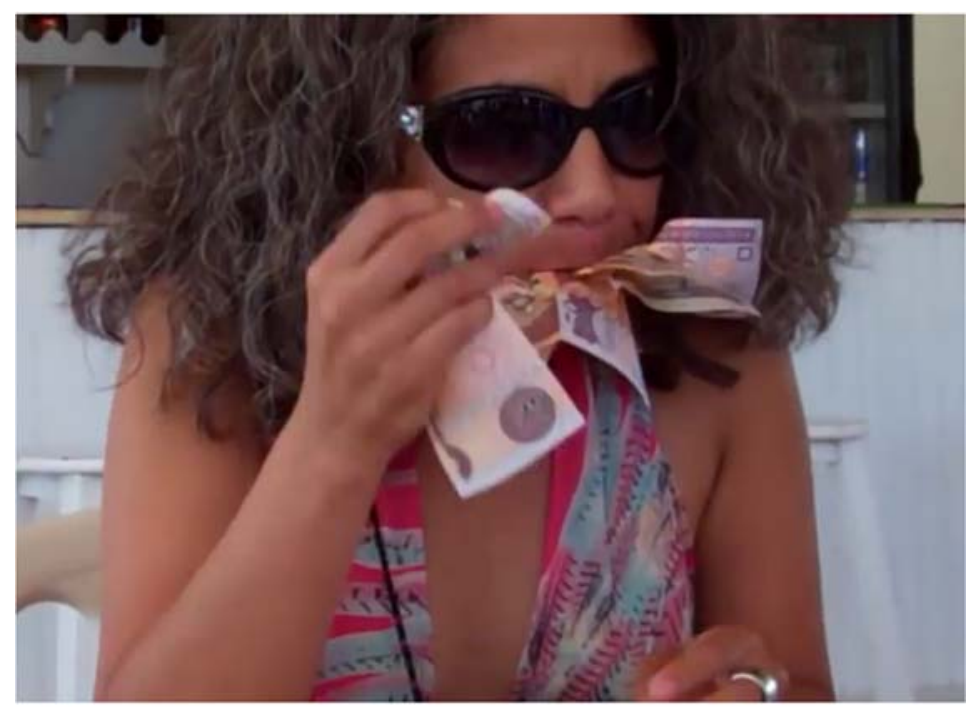

‘Big Money’ (FIG 1)

Neira's artwork 'Inmaculado Corazón' is also a powerful rejection of consumer art which represents empty imitation, devoid of any critical function and whose vacuousness is perpetuated through sheer repetition. Neira's art deliberately does not cater to this market. 'Inmaculado Corazón' parodies both (Chilean) profit-driven consumer and bourgeois art. 'Inmaculado Corazón' is a reworking of an iconic image of the Virgin Mary which has been endlessly reproduced in various forms by consecrated canonical painters such as Sandro Botticelli, by more contemporary artists such as Charles Bosseron Chambers and others. It appears in mass market culture forms on post-cards, T-shirts and digital media. Neira subjects the image to a number of digital manipulations inviting us to reflect on the supposed division of high and low/consumer art and on the concept of authenticity as well as on religious discourses which repress the free expression of female sexuality. She puts her own queer mark on her replica so that that the 'original' iconic image of the Virgin Mary is desecrated as she is now presented as giving an oral fellatio to a disembodied penis, whilst slices of fruit surround the virgin's head in parodic halo fashion. The fusion of the iconic Marian painting with Neira's fruit pieces call to mind the highly exoticised representations of Carmen Miranda. The bright colours and exotic/erotic fruit serve to mock the 'blank' parody ${ }^{\prime 68}$ of mass market kitsch-filled consumer cultural forms (FIG 2).

${ }^{68}$ Fredric Jameson, 'Postmodernism and Consumer Society’, 114. 


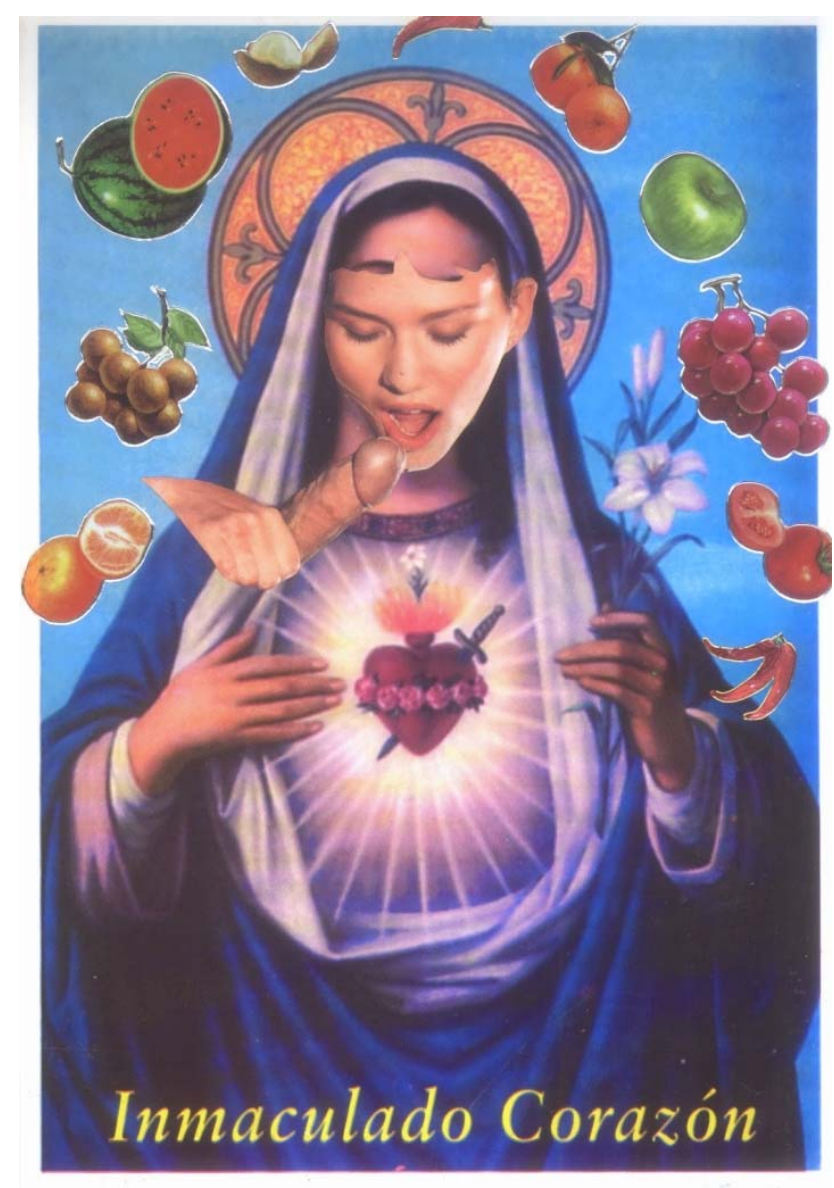

‘Inmaculado Corazón’ (FIG 2).

Even though 'Inmaculado Corazón' is a reproduction of the works of other artists, she does not absorb these mimetically. Therefore, the idea of reproduction is replaced by what Bettina Schmidt has termed 'creative' plagiarism indicating flexible creativity and dynamic adaptation. ${ }^{69}$ By transforming an existing text 'Inmaculado Corazón' becomes an intertextual and intermedial parodic counterattack to notions of influence, authority and authenticity and, by extension, to established conceptions of 'proper' art associated with the classical tradition of depictions of Mary by illustrious (male) painters. By revealing that the 'original' artwork can be easily manipulated, as Neira does in the case of 'Inmaculado Corazón', she undermines what Walter Benjamin terms the 'aura', that is the uniqueness, of the work of art that gives it its 'authenticity' and, therefore, its value. ${ }^{70}$ Her replica divests the original of its authority but arguably leaves the value of her reworking intact so she can sell it online.

In February 2014 at the end of a blog post commenting on the scandal that 'Inmaculado Corazón' caused and the artist's feminist stance in relation to the artwork Neira wrote: 'El feminismo también consiste en esto en elevar la voz y transformar los símbolos que nos

\footnotetext{
${ }^{69}$ Bettina E. Schmidt, Caribbean Diaspora in USA: Diversity of Caribbean Religions in New York City (Hampshire: Ashgate, 2008), 146-7.

${ }^{70}$ Walter Benjamin, 'The Work of Art in the Age of Mechanical Reproduction', in Illuminations, edited by Hannah Arendt (London: Pimlico, 1999), 211-44.
} 
oprimen, asi que ¡Viva la virgen chupapico! (Reproducciones de la obra firmadas se venden a través del mail poesiaccion@gmail.com) ¡Toma!'. ${ }^{71}$ The sudden shift in tone from one informed by feminist political ideology to one which is marked by a marketing intent, has a jarring effect on the reader. By placing this sentence at the end of the entry, Neira seems unwittingly to devalue the socio-political content by appearing to give more weight to the commercial dimension of her art. At the same time, the parody inherent in this sentence cannot go unnoticed. Indeed, the word 'iToma!' ('Take that!') could be seen as a reference to the fact that Neira's reproduction, and not the 'original' version, can be bought with the artist's signature. This could be interpreted as a parody of the manner in which signed products, be it art or memorabilia, for instance, gain commercial value given the high demand of 'original' signatures. Conventionally the signature confers attribution and 'aura' denoting 'the presence of the "author" as the "person who does the uttering," as the "origin," the source, in the production of the statement'. ${ }^{72}$ Whilst Neira's signature is an original, the image which is on sale is a reproduction of manipulated reproductions and the mechanical reproduction diminishes the notion of 'aura', and therefore value, typically attributed to the 'original' signature and to the work of art. We may wonder then about the status of Neira's online store. We have no reason to doubt that we could buy a copy of a manipulated copy of another work with Neira's signature attached but perhaps the joke would be on us as consumers. Instead, we might view the online store as another part of a humorous critique of the way contemporary art is just another consumer product.

The idea of reducing cultural production to a consumer product with a price tag was also mocked at Neira's book launch event for her collection of poems Abyecta. During the presentation for her work, Neira informed the public that her book is ' $\mathrm{a}$ a solo a mil pesos! iporque todo es una oferta, señores!' and later said in English 'Time is money, you know!', quoting President Benjamin Franklin and so attributing the spread of capitalism to the influence of the United States. ${ }^{73}$ Even as she sells her book Neira reserves the right to mock the commercialisation of literature thus embracing and exploiting the contradictions of her 'zona peligrosa'. While Neira critiques the monetization of cultural production she cannot escape from, only to work to subvert from within/at the edges of, an increasingly commercialised cultural arena. She attends book launches, festivals and does interviews, and is active on social media to increase her artistic presence, raising the profile and sales of her work and promoting their dissident agenda. Thus, despite her counterhegemonic stance in relation to the commercialisation of culture, the performance-poet-artist's work and public media persona are, to an extent, also embedded in a neoliberal cultural marketplace.

Neira's exploitation of the Internet in the form of social networking platforms such as Facebook and blogging on the commercial Blogspot platform (owned by Google) have facilitated the

\footnotetext{
${ }^{71}$ Eli Neira, http://elizabethneira.blogspot.co.uk/2014/02/la-nunca-bien-ponderada-virgen-chupapico.html, (accessed 31 March 2019).

${ }^{72}$ Derrida quoted Patricia Allmer, 'La Reproduction Interdite: René Magritte and Forgery', Papers of Surrealism, 5 (2007), 1-19 (p. 11), http://www.surrealismcentre.ac.uk/papersofsurrealism/journal5/index.htm (accessed 31 March 2019).

73 ‘Presentación poemario Abyecta en FILSA 2013’https://www.youtube.com/watch?v=ZpBzVlVuRxk, (accessed 31 $1^{\text {st }}$ March 2019).
} 
commercialisation and promotion of both her work and media personality, as well as opened up the possibility of broadening her public. Although she views the Internet and social media as important 'zonas intersticiales' and an alternative to institutionalised outlets, in so doing she overlooks the way in which, as Mejias signals, these networks are also embedded within the logic of neoliberalism, turning culture into profit:

The argument that digital networks have paved the way for this new "participatory culture" requires us to accept the premise that the continued privatization of the public sphere is the best avenue for social exchange, cultural production, and civic engagement. Notwithstanding experiments in open-source software, peer-to-peer (P2P) file sharing, and so on, digital networks are, at some point or another, for-profit ventures. $^{74}$

Despite being another apparent contradiction, Neira uses social network sites to promote her public self, work, ideology and activism as forming part of an overall fringe aesthetic, and exploits the Internet in order to publicise her performance-poetry or art workshops (with course prices included), to provide details of her forthcoming performances and book launches and to sell her artwork in her 'Tiendita de arte' ${ }^{75}$ This online shop displays her work with prices attached to all the items displayed.

On the one hand, all of these social media-facilitated initiatives point to the creation of what Horning describes as ‘(a) neoliberal subjectivity' which structures 'the self as 'inherently entrepreneurial' ${ }^{76}$ On the other, while Neira offers her audience the opportunity to buy her work she also makes much of her work available to view for free via her website and social media presence and so purchasing her work is not just an economic transaction but a symbolic act of solidarity, albeit one that is ultimately co-opted by the for-profit companies which own the sites. In the end, Neira clearly has to make a living in the 'real' world and in order to do so she reserves the right to exploit those same mechanisms she critiques. In this regard, Neira's mobility across the field of cultural production points to the increasing dissolution of the 'dichotomy of these concepts [centre/periphery] and to a liberation of plurality in terms of artistic practices'. ${ }^{77}$ Just as Richard Peterson has suggested that cultural consumers are increasingly omnivorous so too may we conclude they are producers. ${ }^{78}$ Neira's engagement

\footnotetext{
${ }^{74}$ Ulises A. Mejias, Off the Network, (Minneapolis: University of Minnesota Press, 2013), Loc 573.

75 Eli Neira, 'Tiendita de arte', http://abyectalatiendita.blogspot.co.uk/ (accessed 31 ${ }^{\text {st }}$ March 2019).

${ }^{76}$ Horning discusses how Facebook represents an 'an emerging institution whose function (while seeming openended and eminently flexible (...) is to ground the neoliberal subject, supply it a field where it can be naturalized'. Later, drawing from Wendy Brown (2005) Horning notes that 'The neoliberal state exists only to generate economic growth, and subjects of such state must adapt to suit that goal, adopting individual entrepreneurial goals and values themselves'. Rob Horning, The New Enquiry. Wendy Brown, 'Neoliberalism and the End of Democracy' in Edgework: Critical Essays on Knowledge and Politics edited by Wendy Brown (New Jersey: Princeton University Press, 2005), 37-59.

77 This passage is taken from the description which accompanied the inaugural edition of the 2003 Prague Biennale called 'Peripheries Become the Centre'. http://www.praguebiennale.org/pages/pressarea.php (accessed 31st March 2019).

${ }^{78}$ Richard A. Peterson, 'Understanding audience segmentation: From elite and mass to omnivore and univore'. Poetics 1992 21.4: 243-58. DOI: 10.1016/0304-422X(92)90008-Q.
} 
with Internet technologies and mass media particularly could be seen as an attempt to move towards the type of decentered interconnectedness which prioritises circulation to a wide audience in an open network which, as Shigemi Inaga reports, the Korean Minister of Culture Eo-ryeong suggested will replace existing neoliberal, centralised notions of audience and institutionally-based cultural capital. ${ }^{79}$ As Mejias reminds us, however, we need to exercise caution recognising both the potential freedoms offered by the emergence of such networks whilst remaining attentive to the ways in which:

corporate power seems to curtail that freedom, as corporations retain control over which new features to implement in the network, which members to expel, or even whether the network will continue to exist in the future or not. ${ }^{80}$

\section{Globalization and Interconnectedness - 'Limpieza Colectiva Como Obra de Arte’}

Rather than catering to (Chilean) profit-driven, mass or bourgeois markets and tastes Neira increasingly prioritises counter-hegemonic, deliberately provocative, community and grassroots endeavours that resist neoliberalising agendas in Chile which have entailed the withdrawal of the state in favour of for-profit, sponsor driven, private sector investment in the Arts. Neira seeks out alternative strategies to make her work accessible including, for example, performances in public spaces rather than in galleries and using Facebook to promote and make a living from her work. In so doing, she crosses boundaries, disrupts hierarchies and challenges elitist assumptions about 'culture', its institutions, and its audiences. She takes advantage of the tensions which Andrew Whitworth-Smith has pointed out are at the heart of neoliberal globalization which bring opportunities as well as challenges for those, such as Neira, who seek alternative solutions both by engaging with local communities and global online communities. ${ }^{81}$ While globalization creates 'a greater gap in the distribution of wealth than the world has ever known' and establishes 'Western hegemonic centers - and their elite counterparts in the periphery' as 'the dominant brokers of transnational cultural capital', processes which Neira and others alike seek to undermine, globalization has also engendered 'a greater interconnectivity of peoples of the world, breaking down previously defined spatialtemporal boundaries and, thus, bringing us all, in a sense closer together' and enabling transnational social movements. ${ }^{82}$ It is by drawing on the latter processes that Neira tries to 'exploit' (in the sense quoted above and used by hackers) the opportunities afforded by neoliberal forms of globalisation specifically in the form of the 'otra Internet' which has the potential to foster a sense of interconnectedness and community.

\footnotetext{
${ }^{79}$ Shigemi Inaga in 'Neoliberalism' Elkins, Valiavicharska and Kim eds., Art and Globalization, 89.

80 Mejias, Off the Network, Loc. 618.

${ }^{81}$ Andrew Whitworth-Smith, 'Self-Inscribed Identities: Marginals and Media in the Age of Globalization', Anamesa, Fall 2003 n.p. http://www.nyu.edu/pubs/anamesa/archive/fall_2003_culture/04_whitworth-smith.htm (accessed 31st March 2019).

${ }^{82}$ Whitworth-Smith, 'Self-Inscribed Identities', http://www.nyu.edu/pubs/anamesa/archive/fall_2003_culture/04_whitworth-smith.htm (accessed 31st March 2019).
} 
In using, through choice or otherwise, non-traditional outlets to publish her work Neira joins a growing number of Latin American authors and artists who are making their work available online and in so doing are generating 'new discourses, practices and communities' ${ }^{83}$ Mejias, however, cautions against 'Public intellectuals (media gurus, academics, etc.) who advocate that digital networks are being used to empower the public but who are only undermining our potential to free ourselves from the hypnotic hold of this aestheticized form of sociality' ${ }^{84}$ Taylor and Pitman counter that what is distinctive about internet usage in what they understand as a postnational Latin(@) American context is its propensity to be used 'to organise social activism online'. ${ }^{85}$ Thus, whilst in other contexts online environments are increasingly associated with exclusivity, corporatization and surveillance, Taylor and Pitman optimistically proclaim: 'Latin Americans may well develop "la otra Internet” as a contestatory practice to challenge the hegemony of the Internet as it has spread from the USA outwards' ${ }^{86}$ The work of Eli Neira may be part of this 'otra Internet' and, as we propose, part of a strategy of resistance to the hegemony of cultural institutions and mainstream publishing. Nevertheless, despite her desire to generate 'new discourses, practices and communities' at a glocal level via her direct community (performance) actions and online interventions, so too is she constantly subject to online neoliberal corporatization and surveillance. ${ }^{87}$ The poet-artist's blog carries a warning about explicit content and she frequently has her Facebook account closed down because of, one assumes, her 'inappropriate' criticism about Chilean politics on the environment, for example, or her pro-Mapuche discourse or 'pornographic' 'outrageous' video performances. In this way, as well as providing a model of resistance, Neira's experience of working online also acts as a cautionary reminder of the limits of resistance.

Evidence of a utopian impulse in her work and a desire to break down boundaries is particularly apparent in the performance 'Limpieza Colectiva Como Obra de Arte' through which Neira sought to raise awareness to both local communities and online of (glocal) environmental issues by picking up litter on the Escalera Caracol in Valparaiso and making a video of the performance available on Facebook. Likewise, she put on YouTube a film of the performance 'Tu Patria Está llena de Basura' (2017), in collaboration with the local Valparaíso community and AMAPU decyring the glocal problem of hyperproductivity, plastic waste and the repression and murders of Mapuches in Chile. ${ }^{88}$

By making her work available online to view and, in some cases, purchase online Neira can be seen as producing art which is marked by the context of globalization. The type of work Neira produces and the way in which she disseminates it can be seen as both a product and a symptom of globalization in keeping with Fredric Jameson's suggestion that art in the context of

\footnotetext{
${ }^{83}$ Claire Taylor and Thea Pitman, 'Introduction', in Latin American Cyberculture and Cyberliterature ed. by Claire Taylor and Thea Pitman (Liverpool: Liverpool University Press, 2007), pp.1-30, 1.

${ }^{84}$ Ulises A. Mejias, Off the Network, Loc. 486.

85 Taylor and Pitman, 'Introduction', 7; Claire Taylor and Thea Pitman, Latin American Identity in Online Cultural Production (London: Routledge, 2012), 2.

86 Taylor and Pitman, 'Introduction', 7.

87 Taylor and Pitman 'Introduction', 1.

${ }^{88}$ Neira and AMAPU, ‘ Tu Patria Está Llena de Basura;’ (2017)https://www.youtube.com/watch?v=vq6jMGTbbU (accessed 31st March 2019).
} 
globalization is marked by new forms of production, distribution and consumption. ${ }^{89}$ Globalization, according to Jameson, has led to new kinds of art objects, the use of new forms of communication for distribution, and art which encourages people to engage in new ways to live in a globalized society. Neira's performance-intervention 'Limpieza Colectiva Como Obra de Arte', which was performed free of charge and is freely available to view online, clearly fulfils these criteria by encouraging local and global audiences to become proactively engaged with environmental issues.

In 'Limpieza Colectiva Como Obra de Arte' Neira and some of her students aimed to heighten awareness of environmental issues among local residents of the Escalera Caracol, Cerro Larraín in Valparaiso. For the performance the actors removed rubbish from the staircase in Cerro Larraín as part of what is described as an 'intervención urbana'. In the video posted on Neira's blogsite we see how, as they collect the rubbish and put it in bags for disposal or recycling, some passers-by stop to help or to commend their efforts and at the end the actors are seen meeting with the local neighbourhood association to discuss their efforts and encouraging them to maintain the staircase for themselves in future (FIG 3). ${ }^{90}$

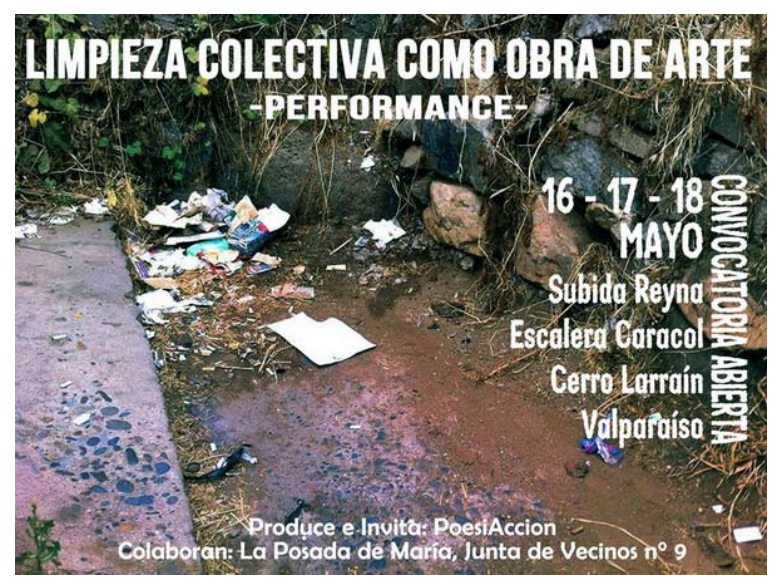

\section{(FIG 3) Poster advertising communal 'Limpieza Colectiva Como Obra de Arte'91}

Some close-up shots focus on the different waste items collected including a bag containing neoprene adhesive, empty wine bottles, cigarette butts and contaminated water source. The items are listed in writing at the end of the film. The video thus highlights the potential health hazards attached to not properly caring for the environment. Instead of seeing this space as

\footnotetext{
${ }^{89}$ Fredric Jameson quoted in the chapter 'The National Situation' which consists of a discussion between Thomas Dacosta Kaufmann, Fredric Jameson, James Elkins, Shigemi Inaga, Pedro Erber, Harry Harootunian, Keith Moxey, Suzana Milevska, Michael Holly, and Simon Baier in Zhivka Valiavicharska James Zhivka Valiavicharska Elkins and Alice Kim eds., Art and Globalization Pennsylvania: Pennsylvania State University Press, 2010), pp.13-22, 14-15.

90 Eli Neira, 'Limpieza Colectiva Como Obra de Arte’, (http://elizabethneira.blogspot.co.uk/2014/06/limpiezacolectiva-como-obra-de-arte.html (accessed 31st March 2019).

${ }^{91}$ http://laotravoz.org/valparaiso-convocan-a-performance-de-limpieza-colectiva-en-el-cerro-larrain/, (accessed 31st March 2019).
} 
disconnected from their lives, residents are invited to become custodians of it in a way which would be mutually beneficial. 'Limpieza Colectiva Como Obra de Arte' demonstrates how performance art is a powerful medium which can provide immediate and real social change by impacting positively, even if minimally, on the lives of disadvantaged communities. As one passer-by remarks: 'pequeños cambios son cosas grandes'. The same message is evident in the graffiti produced by artists as part of the initiative including the statements 'Limpia tu mierda', 'la escurría es nuestra' and 'Saca la basura de tu vida.' This approach is in contradistinction to the cultural politics of neoliberalism which Dávila has shown tend to be inclined 'toward middle-class and upwardly mobile sectors' which 'exclude many cultural workers as well as many residents as consumers and beneficiaries. In this way, far from an added-on ornament that "softens" or ameliorates the social inequalities of neoliberal policies, culture becomes imperative to their production'. ${ }^{92}$

The group filmed their action and made it available on the web in order to bring their message to a wider audience. Furthermore, the performance and accompanying Facebook page ${ }^{93}$ and idea.me site ${ }^{94}$ aimed, apparently unsuccessfully, at crowdfunding further action inviting others, in Chile or abroad, to support further action. The publication of images and videos of the intervention on Neira's blog serves to raise awareness on a global level whilst having a local impact. Such an endeavour therefore constitutes a prime example of the widespread (utopian) tendency to link technology with greater interconnectedness and beneficial social change. Indeed, as Kaya Uzel mentions 'every political movement in recent years has been claimed to be driven by the connectivity that the Internet affords to people attempting to organize for a common cause' ${ }^{95}$ In line with the utopian vision of the internet as fomenting collective social progress, the ideal relationship between people and the environment is imagined on the project Facebook page where we can see an image of a litter-free staircase surrounded by lush plants and flowers. The accompanying post strikingly invites the reader to dream of a future that is even better than the one represented in the picture so that rather than being simply decorative, both man and nature are mutually sustaining:

soñar es gratis (...) quizás algún día la escalera Caracol del Cerro Larraín, lugar donde realizamos la primera "Limpieza colectiva como obra de Arte” se vea así (...) y aún más hermosa pues también quisiéramos que las plantas no solo sean ornamentales sino también comestibles...ojalá algún día estemos tan organizados para que esto suceda... ${ }^{96}$

As well as suggesting that the residents, and by extension the (potentially) global audience watching the video, work together and embrace their connection to the environment, the

\footnotetext{
${ }_{92}$ Dávila, Culture Works, 189.

93 Eli Neira, https://www.facebook.com/events/463347560462631/ (accessed 31st March 2019).

${ }^{94}$ Eli Neira, http://idea.me/proyectos/20481(accessed 31st March 2019).

${ }^{95}$ Kaya Uzel, 'The Material Underside of the Posthuman: Notes on the Foxconn Suicides and the Biopolitics of Outsourced Electronics Manufacturing', Kaleidoscope 5:2. (2013) http://community.dur.ac.uk/kaleidoscope/index.php/kaleidoscope/article/view/74/73 (accessed 31 March 2019). ${ }^{96}$ Eli Neira, Post from 3 August 2014, https://www.facebook.com/limpiezacolectivacomoobradearte (accessed 31st March 2019).
} 
performance points to the responsibility of governments to provide adequate infrastructure which would facilitate such efforts such as recycling. Rather than endorsing an individualistic and economy-driven neoliberal version of globalisation, her performance tries to promote a sense of an interconnected community. This community is firmly rooted in a specific local context but ultimately is made available across national boundaries and has the potential to create a new 'imagined world'. If citizens undertake the task of cleaning up waste voluntarily, however, a neoliberal approach would suggest that the government is justified in withdrawing its resources and saving money. Thus, Neira's act of resistance risks being instrumentalised and becoming expedient in a kind of practice which, Yúdice argues, panders to the neoliberal withdrawal of state institutions and support. ${ }^{97}$ Neira's intention is not to take the place of the state or to endorse its withdrawal, but, as Hollander and Einwohner remind us, intentions are not enough to guarantee that resistance will be successful.

\section{Conclusions}

Neira states that 'Hoy estoy más por la disolución de las identidades en la colectividad' ${ }^{98}$ Her focus on community is apparent in 'Limpieza Colectiva Como Obra de Arte' and subsequent works such as 'Tu Patria Está Llena de Basura' which reach across the boundaries of performance and social intervention as well as across national borders seeking to find a new, collective, in-between space from which to resist social and political injustices as well as the institutionalisation of culture, its privatising urges and focus on the individual. In this space, neither completely within nor without but somewhere in-between, Neira revels in her strategic condescension cultivating her status as a fringe poet-visual artist.

She fosters her own liminal 'zona peligrosa' skilfully negotiating the cracks between genres and media, at the edges of cultural institutions and at the intersection where the global and the local connect. Yet, she seems to be aware that she cannot fully escape the neoliberalising policies which currently prevail in the (Chilean) cultural sphere. Strategies of condescension, such as those employed by Neira in her dealings with FONDART, have undeniably liberating potential but we must remain alert to the ways in which they can be co-opted by the mainstream art world. As Neira tries to subvert the system by taking advantage, critiquing it and uncovering its contradictions, she nevertheless, ambiguously, remains within, albeit at the limits of, existing (patriarchal and neoliberal) structures as shown, for example, in her participation in mainstream cultural events such as in the Poquita Fe poetry festivals, or via the advertising of her work for sale online and her workshops on Facebook. Thus, Neira's experience exemplifies the difficulty of seeking alternatives to 'neoliberalizing systems of value." 99

By eschewing the traditional galleries and institutions, which increasingly aim to monetize culture, and embracing alternative spaces and means of producing art which prioritise the social value associated with fostering global connections, however, Neira can be said to have taken a

\footnotetext{
${ }^{97}$ George Yúdice, The Expediency of Culture: Uses of Culture in the Global Era (Durham: Duke University Press, 2004).

${ }^{98}$ E. Neira, email to authors.

${ }^{99}$ Dávila, Culture Works, 194.
} 
step towards creating alternative 'imagined worlds' as opposed to Benedict Anderson's nationally bounded 'imagined communities' and in opposition to the entrepreneurial mentality that surround[s] them'. ${ }^{100}$ By making her work available and relevant to audiences beyond her immediate national context, Neira attempts to harness the possibilities of online technologies, whilst also being confronted with the ways in which they too are embedded within corporate regimes, to bring pressing issues to international attention and to build transnational communities whilst also aiming to effect change at a national level. Thus, she aims to reach out from her 'zona peligrosa' to establish a counter-hegemonic in-between space in an interconnected world from where she will be better positioned to work with others to challenge diverse injustices as well as neoliberal political and cultural practices.

${ }^{100}$ Appadurai, 'Disjuncture and Difference in the Global Cultural Economy’, 297. 